\title{
POST-AUTHORITARIAN NIGERIA: DEMOCRATIZING UNDER PERVASIVE CORRUPTION
}

\author{
Adeniyi S. Basiru' \\ Olusesan A. Osunkoya²
}

\section{Introduction}

In the last three decades, the global intellectual spaces have been proliferated with scholarly studies which have explored the processes of democratization in the hitherto authoritarian, but now "democratizing" societies of the Global South (see Diamond I995; Alexander 2002). Interestingly, while these studies, would appear to have to added to scholarly understanding of democracy, outside the lenses of the early "democratizers", by identifying conditions under which democracy, once launched, in new democracies, could be safeguarded from break-down or reversal. However, they seem to have been skewed, in focus and orientations towards the experiences of the early "Third Waver" of Latin America, with scanty attention to African countries (see Diamond I996; Mainwaring, O’Donnell and Valenzuela I992; Mainwaring and Scully i995). Even, few Africanist works, such as Villalon and Von Doepp (2006) and Cho and Logan (2009), that focus on Africa, by interrogating the processes of democratization while no doubt, have offered robust arguments to explaining the poor performance of Africa's new "democracies"; sidelined the issue of corruption. Yet, the incidence of corruption, going by the publicity it has been given by regional and global institutions,

I Department of Political Science, University of Lagos, Akoka-Yaba, Lagos, Nigeria. asbash72@yahoo.com

2 Department of History and Diplomatic Studies, Tai Solarin University of Education, Ijagun, Ijebu-Ode, Nigeria.sesanosunkoya@gmail.com 
remains a gargantuan monster that has thwarted the continent's march to sustainable development (Schiller 2000).

It is against the backdrop of this observed gap in the literature that this article, with a focus on post-authoritarian Nigeria, examines the character of democratization process, in Africa, under condition of pervasive corruption. Following this introductory preamble, which sets the background and significance of the study, is the second section that conceptualizes and contextualizes the key concepts that are germane to this study. Section three explores and surveys extant literature on the nexus between democracy and corruption. In the section that follows, the Nigerian experience with democracy and corruption, in the post-Authoritarian era, is interrogated and discussed. Section five develops an explanatory framework for explaining the core problematique in the discourse. The sixth section sums up the arguments, reflects and concludes with a number of submissions.

\section{Conceptual Clarifications: Democracy, Democratic Conso- lidation and Corruption}

At the peak of the Cold War, when authoritarianism of all shades pervaded the socio-political landscapes of Asia, Latin America and Africa, the major preoccupations of democratic theorists seemed to be on how to move the polities of these areas towards liberal democracies. To be sure, during this period, democratization, liberalization, democratic opening, and other liberal-friendly concepts appeared to have been dominant in literature on democracy (see Gillespie I989; Di Palma I990; Linz I990). Nevertheless, as democracies became entrenched in many of these countries, the concept of democratic consolidation became the courted bride of scholars (see Beetham I994; O’ Donnell I996). However, it has to be stressed that while there seems to be a seeming consensus on what democratic consolidation, which Ojo (2008, I70) depicts as making democracy immune against regression into authoritarianism, symbolizes thematically, the concept still faces the problem of homonymy which perhaps makes classification and theory building problematic. In the words of Schedler (I997, 3), "the bad thing is that the uncontrolled use of democratic consolidation has swept us into a state of conceptual disorder that more and more acts as a barrier to subdisciplinary communication, theory-building, and accumulation of knowledge".

Instructively, what thus simply emerged in literature on consolidatology are different conceptualizations of democratic consolidation. This 
notwithstanding, the common denominator of all the major formulations is that all seems to have shifted the definitional scope of democratic consolidation from the classical prism of preventing democracy from "sudden death" (Morlino I995). As Huntington (I996, 9) remarks, "with contemporary neodemocracies, the problem is not overthrow but erosion: the intermittent or gradual weakening of democracy by those elected to lead it". The position of Huntington here is that democratic consolidation, in the post-Cold War era, is no longer about democratic regression into authoritarianism but about converting the democratic players in new democracies into real democrats. In other words, it is now about avoiding or thwarting "slow death" of democracy.

In this wise, definitions of the concept of democratic consolidation began to capture values, institutions, processes and attitudes that tend to support or strengthen the democratic processes. For example, Bratton (I999) conceptualizes it as the widespread acceptance of roles to guarantee political participation and political competition. From a slightly different angle, Ojo (2008; I970) sees it as the process by which democracy becomes so broadly and profoundly legitimate among citizens that it is very unlikely to break down. In a similar vein, Diamond (I995) says it involves the behavioural and institutional changes that normalize democratic politics and narrows its uncertainties. He adds that such normalization requires the expansion of citizen access, development of democratic citizenship and culture, broadening of leadership recruitment and training among others.

To be sure, the connecting thread in these definitional perspectives is that democratic consolidation is depicted as a process of progressing from the spectrum of consolidating democracy towards that of consolidated democracy. In other words, democracy is said to be consolidated when democratic regimes of the post-authoritarian society has completely shed themselves of the remnant of authoritarianism and have attained the level that might be impossible to regress into pseudo or hybrid forms of democracy. In this context, Whitehead is of the view that, "democracy can best be said to be sustained or consolidated only when we have good reason to believe that it is capable of withstanding pressure or shocks without abandoning the electoral process or the political freedom on which it depends, including those of dissent and opposition" (I989, 40). Similarly, Przeworski (I99I, 93) contends that democracy is consolidated when the major political players recognize sufficient common interest in establishing electoral procedures and subsequently see what their interest in keeping to the rules of the game outweighs the costs to them of their being underpinned rather than out of any principled commitment to democratic norms and cannons. 
However, beyond the foregoing contentions and theses, some scholars on the subject are, conversely, of the view that rather than dissipating so much intellectual energies in pinning down a concise definition of democratic consolidation, emphases should be on its sine qua non (Beetham I994; Schedler I998). Specifically, this emerging orientation posits that once these conditions are habituated in new democratizing polities, the prospects of democratic reversal or even death are halted. In extant literature on democratic consolidation, these conditions are presented as substantive and stability factors (Svolik 2007). Instructively, the first is symbolized in the multiplicity of institutions, norms and beliefs that could nurture democracy in new democracies (Guillermo and Philippe i986). The second depicts conditions that promote legitimacy and stability of the democratic order (Schedler I997). In the words of Ogundiya (2010, 235), "the tiny gap between stability and consolidation is that stability begets consolidation. Put differently, democracy must be stable for it to be consolidated".

Stemming from the foregoing, therefore, democratic consolidation would appear to suggest the capacity of a country to nurture legitimizing values over a long time with little or no threat to democratic project. It would also seem to suggest the taming of antimonies that could delegitimize the new democratic order and makes it vulnerable to authoritarian reversal. Perhaps, it is within this framework that the link between corruption and democratic consolidation has been framed in the post-Cold War era. However, before the link is explored, it is apposite, for the purpose of this discourse, to put the concept of corruption, in the right perspective.

\section{Defining Corruption}

The concept of corruption lacks a universally accepted definition, and universal consensus about its meanings (Heidenheimer et al. I989). This fact notwithstanding, attempts have been made by scholars and institutions to define corruption. While Nye (I967, 4I7) conceives it as "behaviour that deviates from the formal duties of a public role (elective or appointive) because of private-regarding (personal, close family, private clique) wealth or status", Huntington (I968) views it as the behaviour of public officials which deviates from the accepted norms in order to serve private end. Dobel (I978) construes corruption as the betrayal of public position, resources and power for private gain. For the World Bank $(1997,7)$, it is "the misuse of public power for private gains". However, contrary to the perspectives of Nye, Huntington and the World Bank that conceives corruption narrowly 
from an official angle, Otite (I986) offers a broader definition of corruption. He construes corruption as the perversion of integrity and state of affairs through bribery, favour or moral depravity. The import of Otite's definition is that it captures the moral as well as the distortion of procedures. This conceptualization underscores the fact that corruption is a phenomenon that straddles all sectors of the society (Basiru 20I4). However, for the purpose of this article, the definitional perspective of corruption is framed in the context of malfeasance and misconduct in the governmental circle bordering on an abuse or misuse of official power by elected/appointed public officials for private gains. To be sure, this perspective seems to conform to the position of the African Union (AU), which, in its Convention on Preventing and Combating Corruption and Related Offences, adumbrates acts of corruption in the governmental sector to include:

- The solicitation or acceptance, directly or indirectly by a public official or any other person, of any goods of monetary, or other benefit, such as a gift, favour, promise or advantage for himself or herself or for another person or entity, in exchange for any act or omission in the performance of his or her public functions;

- The offering or granting, directly or indirectly, to a public official or any other person of any goods of monetary value, or other benefit, such as a gift, favour, promise or advantage for himself or herself or for any person or entity, in exchange for any actor omission in the performance of his or her public functions;

- The offering or granting, directly or indirectly, to a public official or any other person for the purpose of illicitly obtaining benefits for himself or herself or for a third party;

- The diversion by a public official or any other person, for purposes unrelated to those for which they were intended, for his own or her own benefit or that of a third party, of any property belonging to the state or its agencies, to an independent agency, or to an individual, that such official has received by virtue of his or her position;

- The offering or giving, promising, solicitation or acceptance, directly or indirectly, of any undue advantage to or by any person, who directs or works for, in any capacity, a private sector entity, for himself or herself or for anyone else, for him or her to act or refrain from acting, in breach of his or her duties; 
- The offering, giving, soliciting or accepting directly or indirectly, or promising of any undue advantage to or by any person who asserts or confirms that he or she is able to exert any improper influence over the decision-making of any person performing functions in the public or private sector in consideration thereof, whether the undue advantage is for himself or herself or for anyone else, as well as the request, receipt or the acceptance of the offer or the promise of such an advantage, in consideration of that influence, whether or not the influence is exerted or whether or not the supposed influence leads to the intended result;

- Illicit enrichment;

- The use or concealment of proceeds derived from any of the acts referred to in this article; and

- Participation as a principal, co-principal, agent, instigator, accomplice or accessory after the fact or in any other manner in the commission or attempted commission of, in any collaboration or conspiracy to commit, any of the acts referred to in this article (AU 2003).

\section{Democracy and Corruption: Navigating the Nexus}

It has to be stressed that the debates about whether democracy when consolidated reduces the incidences of corruption or strengthens it, in literature, has been dominated by two contradictory perspectives. The first, as documented in the works of Langseth (I999), Kolstad and Wiig (201I) among others, contends that democracy when consolidated in a country is a powerful tool to reducing corruption. The core thesis of this school of thought is that, given the accountability framework, inbuilt in a constitutional democracy, not present in an autocracy, a culture of accountability and transparency, which eschews corruption, is more likely to be cultivated and sustained. Working within this framework, Linz and Stepan (1996), Sandholtz and Koetzle (2000), Chowdhury (2004) and Batzilis (2015) insist that democracy, through elections and other accountability mechanisms inherent in it provide effective means for the citizens and the opposition parties, for detecting and punishing corrupt practices.

Specifically, Sandholtz and Koetzle $(2000,42)$ posit, "in a democratic regime, the populace acquires more extensive and effective means of 
detecting and punishing corrupt practices". Joining issues with Sandholtz and Koetzle, Osopian (2013) argues that competition among political parties inherent in liberal democracy acts as a "check" on each other's behavior and by so doing, imposes a sense of accountability that, in the long run, reduces incidences of corruption. As he avers, "it induces politicians to avoid allegations of corruption if their party is seeking re-election" Osopian (2013). Echoing Osopian's view, Chowdhury (2004) posits,

It is in the interest of opposition parties to uncover any of their opponents who are engaging in corruption. Not only does this encourage greater transparency in the political process, it firmly incentivizes the incumbent government to meaningfully engage in the fight against corruption.

Instructively, beyond the check inherent in electoral and party competition in a liberal democracy, it is also contended that the horizontal accountability institutionalized in a system of check and balances, between the three organs of government, equally reduces the incidence of corruption (see Persson I997; Laffont and Meleu 200I). Putting this perspective, Barro (1999) avers "checks on governmental power are necessary to limit the potential for public officials to accumulate personal wealth and carry out unpopular policies". Furthermore, Saha et al. (20I4) posit that, "by expanding democracy, one is increasing the probability of the detection and punishment of corruption and in turn, reducing the proportion of bribe-takers".

Conversely, the second argument, drawing from the experiences of the late democratizers and discerned in studies such as Case (2002), Fisman and Gatti (2002), Mohtadi and Roe (2003), McLeod (2005) and Rock (2007), posit that democracy does really reduce the incidence of corruption in democratizing societies. Specifically, Rose-Ackerman (I996) remarks that, "even consolidated democracies are not short of their own forms of corruption". The contention here is that the institutionalizations of democratic reforms in a country do not necessarily lead to reduction of incidences of corruption but rather it tends to "re-package" corruption in new form (see Hicken 200I; Robison and Hadiz 2004).

At this juncture, it has to be stressed that while both perspectives, no doubt, are robust and illuminating, however, the second, as it will soon be presented, would appear to be applicable for our purpose in this article, even though, it has been framed in the context of the experiences of illiberal democracies of Asia, for the simple reason that it captures the political realities of Africa's democratizing polities ravaged by pervasive corruption. 
However, it fails to capture the relationships between democracy, institutions, development and corruption. It equally fails to factor into its explanatory lens the incompatibility of the institutions of liberal democracy to Africa's cultural milieu and how this has shaped the quality of the democratization project in Africa (see Ake I99I; I993; 2000; Parekh I993; Mafeje I995; Mkandawire I999; Lumumba-Kasongo 2005; Finkel et al 2008; Rutazibwa 20I4). We will come to this soonest but before then, it is imperative to examine the capacities of the institutions of liberal democracy in post-Authoritarian Nigeria to reduce the incidence of corruption. This is the focus of the next section.

\section{Democracy and Corruption in Post-Authoritarian Nigeria: An Overview}

On 29th May, I999, Nigeria, after almost fifteen years of military autocracy, returned to a liberal constitutional order, perhaps, with much expectation that the new order would be remarkably different from the previous republics, which collapsed due to wanton corruption of the political class (Falola and Ihonbvre I985; Joseph I99I). Prior to this era, the country, aside occupying a pariah status in the comity of nations, as a result of poor human rights records by the various military regimes that superintended its affairs, the country occupied the first five positions in the Transparency International's Corruption Perception Index (Transparency International I999, I).

Indeed, few weeks before the inauguration of the first democratically elected government, the country was voted the most corrupt country in the world (Enweremadu 20I2). Perhaps, it was this sorry state of affair that compelled the first President of the new dispensation, Olusegun Obasanjo, upon assumption of office, to make the fight against corruption the cornerstone of his domestic policies (Ribadu 2006, I). His successors, including the incumbent, Muhammadu Buhari, have equally put in place, legal and institutional measures, to deal with corruption in the country (Basiru 2018, I30).

However, in spite of these efforts, the monster of corruption, especially among government officials, based on the observation of the political scenes since the country re-democratized, remains as pervasive as it was under authoritarian order, with attendant implications for democratic consolidation (Basiru 20I4, 78). Clearly, this suggests that the post-authoritarian Nigerian democratic institutions, notably the legislatures, judiciary, political parties, electoral systems, etc., that should be the anchorages of the institutional architectures to tame corruption, as is the case in matured 
democracies, have not really attenuated the incidences of corruption in the country (Duruji and Azuh 20I6). Indeed, it would appear that rather than move in the direction of democratic consolidation, the country seems to have demonstrated that democratization also has the potential to establish a new patronage system (Basiru 20I6). To be sure, this state of affairs, in the last I8 years, has manifested in many fronts. In the first instance, it has manifested in the institution of elections in the country. How? By virtue of its historic mandate, elections are the primary mechanism through which the citizens, through universal adult suffrage, hold the elected officials accountable and by extension, reducing their appetite for greed (Lederman et al. 200I). Indeed, a well known verdict in liberal jurisdictions, where the voters are really sovereign, is that dissatisfied electorates (citizens) have the rights to vote another party, spoil their ballot or abstain from voting altogether (Batzilis 2015, 32). This leverage, in a way, contends liberal theorists, some of which works were reviewed earlier, puts pressure on the incumbent office holders to constrain their greed and align their interests and policies with those of the electorates (see Bebchuck and Fried 2004).

However, the opposite of the foregoing liberal ethos seems to have been the case in post-authoritarian Nigeria where incumbent office holders hardly see elections as the leverage for the electorates that are dissatisfied with their performance to change them through the ballot (Ibrahim 2007; Akhaine 20II). Indeed, at different levels of government in the country in the last I 8 years, there have been numerous cases in which the incumbents accused of corruption and abuse of office, have won elections through manipulation and fraud (Agbaje and Adejumobi 2006). Beyond this, incumbents also continue to manipulate the electoral processes to legitimize the retention of power and also deploy state machinery to pursue their selfish interests. The point being made here is that elections, in post-authoritarian Nigeria, like they were, in the previous republics, have become mere periodic rituals only for the exercise of franchise and not for holding political office holders accountable to the electorate (Onoja 2007, 9).

More worrisome in the whole episode has been the seeming weakness of the Electoral Management Body (EMB), charged, constitutionally, to conduct elections, in discharging its responsibilities. Indeed, at a point, it seemed as if the body was an arm of the People Democratic Party (PDP), the ruling party at national level from 1999 to 2015 . For instance, in the run up to the 2007 Presidential election, the electoral body, through its Chairman, Professor Maurice Iwu, jettisoned the age-long principle of the impartiality of the electoral body, by usurping the power of the Judiciary, to determine the candidate that had the right to contest the presidency of the 
country (Iyayi 2007). In fact, it took the intervention of the highest court in the land, barely 72 hours before the 2007 presidential poll, to include the logo of the candidate of the leading opposition party on the ballot.

Equally important to be stressed is that the opposition parties have also been found wanting in the country's democratization processes in the last i 8 years. Ideally, opposition parties, as shadow governments, should, in conjunction with the civil society organizations (CSOs), be the vanguard of holding the officials in power accountable to the citizens. In the words of Osipian (2013),

competition encourages opposition parties to act as a 'check' on each other's behaviour. Revelations of corruption can impose reputational costs for wrongdoing, demand public inquiries and encourage the dismissal of elected politicians and bureaucrats.

In most liberal democracies, it is customary for the opposition parties in their own interest to uncover any of their opponents that are engaged in corruption. Instructively, an attitude such as this does not only check and encourage greater transparency in governance but would also constantly put the incumbents in a position to engage in meaningful fight against corruption in the society. Conversely, in Nigeria and other democratizing polities in Africa, the opposition parties, have, in the last few years, have hardly played this critical role. Even beyond this, political parties in Nigeria, in the last I 8 years, have been documented to have been bedeviled by several pathologies, which have impacted on their supposed roles in a democratizing Nigeria (Anifowose 2004; Adejumobi and Kehinde 2007; Olarinmoye 2008; Omotola 20I0; Basiru 20I5). However, one of such pathologies that seems to have impacted negatively on the capacities of political parties in Nigeria to play the role of opposition and by extension, fighting corruption, has been ideological vacuity (Omotola 2009; Ogundiya 20II).

Observably, Nigerian major political parties are hardly different from one another in term of ideology. Indeed, as it is generally remarked in Nigeria, political parties are mere vehicles for getting into public office for the sake of accumulation. In other words, politicians in Nigeria are not, based on ideological belief, interested in strengthening the opposition for purpose of questioning and challenging the actions and policies of the party in power. Rather, they are interested in getting into offices via any available party. In Nigeria, every politician wants to be in the ruling party rather than being in the opposition. Putting the switching mentality of Nigerian politicians in perspective, Ikuenbor (2OIO, I4) posits, 
there is a striking similarity between politicians and prostitutes as the endeavours of both professionals are geared towards the acquisition of power and money respectively; both glowing in their adulterous eyes. In both professions, switching is the game. However, while prostitutes switch beds, the politicians switch parties.

Another sphere in which the democratic institutions of the post-authoritarian Nigeria would appear to have failed is that of horizontal accountability. Again, as liberal theorists, aver, state power should be balanced between the executive, legislature and the judiciary so as to prevent abuse of power by one organ of the state (Merkel 2006, 29). Put differently, each organ of the state is accountable to the other, within the limit of its allotted constitutional power, to stop, watch and block their actions. The logic here is that by curtailing the individual political actor's political discretion, his ability and capacity to indulge in selfish and greedy practices is restrained (Kolstad and Wiig 20II). In Nigeria, in spite of the institutionalization of the principle of horizontal accountability in the 1999 Constitution, the legislatures, at both the centre and the peripheries of the Nigerian federation, would appear to have performed dismally in checking the corrupt practices of members of the executives (Imam and Mustapha 2008; Alabi and Fashagba 20I0). In several documented instances, members of the legislature have rather than protecting the interests of the electorates and the citizenry actually prebendalized with the executive to the detriments of the country (Basiru 20I4).

At another level, the legislature itself that ought to be the vanguard for checking the executive on how it deploys public financial resources, was, in many documented cases, enmeshed in corruption. Indeed, between I999 and 2003, the leadership of the upper legislative chamber changed two times due to crisis bothering on corruption. Indeed, the situation seems not to have changed in the current $\left(7^{\text {th }}\right)$ National Assembly (Saliu and Bakare 20I6). Few months ago, Hon. Abdulmumuni Jibril, the erstwhile Chairman of the Appropriation Committee, alleged that the House of Representatives, the lower chamber of the National Assembly, of which he is a key officer, stink with corruption (The Nation 2016 , 4). Indeed, no Nigerian better captures the rot in the National Assembly in Nigeria than the first President in the $4^{\text {th }}$ republic, Olusegun Obasanjo who asserted that the both legislative houses are an assemblage of thieves and looters (Awela 2016, I). Here, it is equally instructive to stress that the judiciary, the arm of government that is constitutionally charged with the mandate of checking the abuse of power of the two other arms, at the federal and state levels, in the last i8 years of democratization, has also performed dismally, especially, in the sphere of ensuring public 
accountability (Enweremadu 20II). Indeed, aside from being confronted with the challenge of weak institutional capacity to perform its functions, the judiciary itself, like its sister organs, has been enmeshed in crisis of credibility bothering on corruption (Osipitan 2005, I4). Although, it must be noted, allegations of corruption against members of the judiciary did not berth with the advent of the $4^{\text {th }}$ republic, the tempo of such allegations would appear to have further heightened in the republic (Enweremadu 20II). As a retired Justice of Supreme Court, Justice Samson Uwaifo, observes in 2005,

Corruption was once thought to be only in the magistracy because of the disturbing way some of the personnel tended to abuse their office ... It gradually crawled to the High Courts and would appear to have had a foothold among a noticeable number of judicial officers there ... Now, there is real apprehension that the appellate court may soon be infested if not already contaminated with some of these vices (Thisday 4 June 2005, I6).

In the last I 8 years of democratization in the country, several judicial officials have been dismissed from the Bench (Thisday 4 June 2005, I6). In October, 20I6, for the first time in the political history of the country, some high profile judges, in "string operation" by the operatives of the Department of State Security (DSS), the internal intelligence arm of the Nigerian state, were arrested, in a coordinated manner, across major cities in the country (Vanguard 8 October 20I6, 8). Although, the processes of their prosecution by the Nigerian state is in progress but the fact that such operation took place in the first instance clearly suggests the malfeasance in the country's temple of justice.

The foregoing discussions are pointers to the fact that the democratic institutions, put place in the course of transiting from an authoritarian order into liberal democracy, in the last I8 years, had not really lived up to expectations in curbing the monster of corruption as has been hoped for by the western promoters of political liberalization. To be sure, the institutions that have been constitutionally mandated to promote democratic accountability, probity and transparency in Nigeria, have, rather than discharging their mandates, been immersed in cesspool of corruption with serious consequences for social order and by extension, democratic consolidation. At this juncture, a question is apt: why has the problem of corruption, in spite of longevity of democratic practice, persisted? 


\section{State, Liberal Democracy and Corruption in Nigeria}

The seeming failure of democratic institutions in post-authoritarian Nigeria, like in the previous republics, to deal with the monster of corruption, can really be explained from two mutually reinforcing positions. Therefore, the first thesis that is proposed is that at the root of the problem lies in the character of the Nigerian state and the politics it engenders. As Ake $(2000,7)$ remarks, "much of what is uniquely negative about politics in Africa arise from the character of the state, particularly its lack of autonomy, immensity of its power, its proneness to abuse, and lack of autonomy and lack of immunity against it”. Framed this way, the post-colonial Nigerian state, though immense and over developed in term of power, is, however, not autonomous of the dominant social forces. To this end, it is easily captured by a tiny minority, which often deploys its awesome power to achieve selfish objective, most importantly, to accumulate wealth at the expense of the majority of the citizens.

In this wise, it has become an arena of intra-hegemonic struggles, among the tiny minority to capture it, for purpose of primitive accumulation. Instructively, the captor in a democracy, a political party, upon ascension to state power often deploy all available resources at its disposal to remain in power, for the simple reason that retention of power offers leeway for continued access to the country's commonwealth. In a political arrangement such as this, state offices become prebends that can be appropriated by state officials to accumulate wealth not only for themselves but also for a network of clients beneath the state (Joseph I987). According to Thomson (2000, II9),

Clientelism is a mutually beneficial association between the powerful and the weak. A patron extends public office (a salary or access to the state), security (something akin freedom from arbitrary violence) and resources (such as wells, roads, medical centres) to his or her clients. In return, the client offers supports and deference that help the patron's elevated position.

Instructively, as clientelism pervades the entire social system, even those democratic institutions that are to ensure public accountability have become caught in the web of prebendal culture, whereupon, corruption and other genres of official malfeasance became the order of the day (Yagboyaju 20II). The point being made here is that the post-colonial Nigerian state like its peers elsewhere in Africa is an arena for the distribution of prebends and patronage. However, as fascinating as this explanatory framework is, it 
cannot be divorced from the country's colonial past. Indeed, many scholars of African politics have traced the origin of state-society schism in general and corruption, which has impacted negatively on the democratization processes in the continent to debauchery of colonial rule. For Ekeh (I975), colonialism created in Nigeria two set of values, which were oriented differently towards two publics: the primordial and civic. The former, according to him, is a bastion of morality in which the natives (Nigerians) considered as sacred and thus related to it with deference. The latter, on the other hand, is associated with the exploitative colonial rule and represented amoral domain to be pillaged and plundered by the natives to build up or support the primordial domain and thus making corruption, nepotism, favouritism, etc., the hallmark of the state (public realm). Within this logic, therefore, it became legitimate to embezzle state funds to nourish the primordial realm. Instructively, since the state, given the rudimentary development of capitalism, is the custodian of the country's commonwealth, as remarked earlier, it has become the honeycomb to be pillaged by the tiny minority, which has captured it via elections, for the purpose of distrusting prebends. In a democracy, it is not only the executive arm of the state that is prebendalized but all other democratic institutions.

Reinforcing the foregoing is the second thesis, which links the problem to the throwback of the incompatibility of institutions of liberal democracy to Africa's environment (see Teshome-Bahiru 2008). Yet, the promoters of this brand of democracy have insisted that it is what Africa need. Alas, liberal democracy itself is rooted in a specific culture. In the words of Adetula (2OII, I7), "the evolution and development of liberal democracy is associated with a particular culture and environment, which belies its claim to universality. Given this major constraint, its transferability to different cultural contexts has generated many problems, especially for non-western societies. The purveyors of liberal democracy ignore the differences in the process of historical development and change in different regions of the world". In his seminal work on the cultural relativity of liberal democracy, Ake (I993) contends that liberal democracy, given its roots in atomistic social order, does not fit into the African context. Based on this premise, he submits that the model of democracy that is fitting for Africa and Africans is different from liberal democracy being promoted by the donor agencies. Re-echoing Ake's position, Parekh (I993), Shivji (2003), Adetula (20II) and Rutazibwa (20I4) insist that liberal democracy, irrespective of how it has been packaged by the West and their institutions, is not in tandem with Africa's realities. Its imposition on Africa as a corollary to the structural adjustment programmes by the West has resulted in the proliferation of institutions (some of which 
were discussed earlier) that are either weak, incapable or caught in the quagmire of corruption.

\section{Concluding Remarks}

This article set out to examine the contours and terrains of democratization process, in a democratizing Nigeria, under condition of pervasive corruption. From the evidence gathered in the course of the study, it was found out that endemic and pervasive corruption, especially in official quarters, have constituted a major threat to democratic consolidation in post-authoritarian Nigeria. It was also demonstrated that democratic institutions in post-authoritarian Nigeria have been so weak in checking the incidence of corruption in the country. It noted that unlike the scenario in the advanced liberal democracies where democratic institutions are alive to their historic mandates of checking corrupt practices, the opposite have the case in Nigeria. Resultantly, this state of affairs has had implications not only for the country's development and but also democratic consolidation. At the centre of the problem is a non-autonomous, prebendal petro-state whose arena has been providing fertile grounds for corruption and all genres of official malfeasance to thrive. In the light of the foregoing, what should be done? Firstly, it is suggested that the democratic architectures of Nigeria and other African countries will need to be re-examined, decolonized and if possible reworked as to re-orient them towards a model of democracy that does not only fit into the country's socio-cultural milieu but can also improve the material conditions of the people. Secondly and ultimately, the entire Nigerian structure needs to be reconstructed via an autochthonous process. The Nigerian state as it is presently constituted is alien to the people; it needs be indigenized, decolonized and democratized.

\section{REFERENCES}

Adejumobi, S. and Kehinde, M. 2007. "Building Democracy without Democrats." Journal of Africa Election, 6, 2: 12-23.

Adetula, V. 20II. "Measuring Democracy and 'Good Governance' in Africa: A critique of assumptions and methods." In Governance in the 21st Century: Africa in Focus, edited by K. Kondlo and C. Ejiogu. Pretoria: Human Sciences Research Council. 
Agbaje, Adigun and Adejumobi, Said. 2006. "Do Votes Count? The Travails of Electoral Politics in Nigeria." Africa Development, XXXI, 3: 25-44.

Ake, C. I99I. "Re-thinking democracy in Africa." Journal of Democracy, 2, I: $32-44$.

Ake, C. I993. "Unique case for African democracy." International Affairs, 69, 2: 239-244.

Ake C. 2000. The Feasibility of Democracy in Africa. Dakar: Council for the Development of Social Science Research in Africa.

Ake, C. 2000. Democracy and Development in Africa. Ibadan: Spectrum Books.

Akhaine, Sylvester et al. 20II. "Fair Polls or Foul Polls, the controversy goes on." The Constitution, II, 2: II6-I3I.

Alexander, G. 2002. The Sources of Democratic Consolidation. New York and London: Cornell University Press.

Alt, J.E and Lassen, D. D. 2005. "Political and Judicial Checks on Corruption: Evidence from American State Governments." Economic Policy Research Unit Working Paper Series. http://www.econ.ku.dk/epru/ files/wp/wp-05-I2.pdf.

Anifowose, Remi. 2004. "Political Parties and Party System in the fourth republic of Nigeria: issues, problems and prospects." Issues in Nigeria's 1999 General Elections edited by L. Olurode and R. Anifowose. Lagos: John West Publication Limited.

AU. 2003. "Convention on Preventing and Combating Corruption." AU Ass. Dec. 27 (II), para.2, AU Doc. Assembly/AU/Dec.27 (II). AU: Maputo.

Awela, V. 20I6 "Obasanjo rubbishes National Assembly, says it's an assembly of thieves, looters." Information Nigeria, July I5, 20I6. http:// www.informationng.com/2016/07/obasanjo-rubbishes-national-assembly-says-its-an-assembly-of-thieves-looters.html

Barro, R.J. I999. "Determinants of democracy.” Journal of Political Economy, 107, 6: 158-183.

Basiru, Adeniyi. 20I4 "The Festering Sore of Corruption in Africa and its Implications for Democratic Consolidation." Africa Insight 43, 4.

Basiru, Adeniyi. 20I5. "The Images of Political Parties in Contemporary Nigeria." Ibadan Journal of Sociology, 2: 82-106. 
Basiru, Adeniyi. 20I6. "Imperial Presidency and the Neo-patrimonialization of Disorder in post-Authoritarian Nigeria." Contemporary Journal of African Studies, 4, I: 52-72.

Basiru, Adeniyi. 2016. "Democracy Deficit and the Deepening Crisis of Corruption in Post-Authoritarian Nigeria: Navigating the Nexus." Taiwan Journal of Democracy, vol. I4, no. 2, pp.I2I-I42.

Batzilis, D. 20I5. "Does Electoral Competition Reduce Corruption? Evidence from Municipality Audits in Greece." Job Market Paper, March I7, 2015 pp. I-56. http://home.uchicago.edu/ batzilis/jobmarketpaper. pdf.

Bebchuck, L. and Fried, J. 2004. Pay Without Performance. Cambridge: Harvard University Press.

Bratton, Michael. I998. "Second Elections in Africa." Journal of Democracy, 9, 3: 6-35.

Case, W. 2002. Politics in Southeast Asia: Democracy or less. New York: Routledge Curzon.

Cho, W and Logan, P. 2009. "Looking Toward the Future: Alternations in Power and Popular Perspectives on Democratic Durability in Africa." Afrobarometer Working Paper no. IIo (August).

Chowdhury, S. K. 2004. "The effect of democracy and mass media on corruption: an empirical test." Economics Letters, 85, I: 93-IOI.

Di Palma, Guiseppe. 1990. To Craft Democracies: An Essay on Democratic Transition. Berkeley: University of California Press.

Diamond, Larry. I995. "Promoting democracy in the I990s: Actors and instruments, issues and imperatives." A Report to the Carnegie Commission on Preventing Deadly Conflict. New York: Carnegie Corporation.

Diamond, Larry. I995. "Rethinking Civil Society: Towards Democratic Consolidation." CROSSROAD: A publication of the United States Information Service, Lagos, Nigeria, Part A\&B: I-5.

Diamond, Larry. 1996. "Democracy in Latin America: Degrees, Illusions, and Directions for Consolidation." In Beyond Sovereignty: Collectively Defending Democracy in the Americas edited by Tom Farer, Baltimore and London: Johns Hopkins University Press.

Dobel, John. I978. "The corruption of a state." American Political Science Review, 72, 3: 958-973. 
Duruji, M. and Azuh, D. 20I6. "The Challenges of Combating Corruption in Nigeria." In The State in Contemporary Nigeria: Issues, Perspectives and Challenges, edited by S. Omotola and I. Alumona. Ibadan: John Archers.

Ekeh, P. P. I975 "Colonialism and the Two Publics in Africa: A Theoretical Statement." Comparative Studies in Society and History I7,I: 9I-II2.

Enweremadu, David. 20II. "The Judiciary and the Survival of Democracy in Nigeria: Analysis of the 2003 and 2007 Elections." Journal of African Election, IO,I: II4-I42.

Enweremadu, David. 2012. Anti-corruption campaign in Nigeria (1999-2007). Leiden: African Studies Centre.

Falola, Toyin and Ihonbvre, Julius. 1985. The Rise and Fall of the Second Republic. London: Zed Books.

Finkel, S. E et al 2007. "The effects of US foreign assistance on democracy building, 1990-2003.” World Politics 59 (April): 404-439.

Fisman, R. and Gatti, R. 2002. "Decentralization and corruption: evidence across countries." Journal of Public Economics, 83: 325-345.

Gillespie, C. 1989. "Democratic Consolidation in the Southern Cone and Brazil: Beyond Political Disarticulation?” Third World Quarterly, II, 2. 92-II3.

Guillermo, A.O and Philippe, C.S. I986. Transitions from authoritarian rule: Comparative perspective, Vol. 4. Baltimore, ML: Johns Hopkins University Press.

Heidenheimer, A.J et al I989 Political Corruption: A Handbook. New Brunswick: Transaction Publishers.

Hicken, A. 200I. "Governance and growth in Thailand." In A Corruption: The Boom and Bust of East Asia, edited by J.E Campos. Manila: Ateneo de Manila University Press.

Huntington, Samuel P. I996. "Democracy for the Long Haul." Journal of Democracy, 7, 2.

Huntington, Samuel. 1968. Political Order in Changing Societies. New Haven: Yale University Press.

Ibrahim, Jibrin, 2007. "Nigeria's 2007 Elections: The Fitful Path to Democratic Citizenship." Special Report 182, United States Institute of Peace, Washington, DC.

Iyayi, Festus. 2007. "Election, INEC and the Problem of Election Mindsets in Nigeria." The Electoral Journal, I: 14-26. 
Joseph, Richard. I99I. Democracy and Prebendal Politics in Nigeria: The Rise and Fall of the Second Republic. Ibadan: Spectrum Books.

Joseph, S. ed. I995. The Consolidation of Democracy in Latin America. Boulder and London: Lynne Rienner.

Kolstad, I. and Wiig, A. 20II. "Does democracy reduce corruption?" CMI Working Paper 4, 20II: I-25. http://www.cmi.no/publications/ file/43I5-does-democracy-reduce-corruption.pdf.

Laffont, J.J and M. Meleu, M. 200I. "Separation of powers and development." Journal of Development Economics, 64: I29-I45.

Langseth, P. I999. "Prevention: An Effective Tool to Reduce Corruption." A Paper presented at the Global Program against Corruption Conferences, Vienna, December 2, I999. http://www.unodc.org/pdf/ crime/gpacpublications/cicp2.pdf.

Lederman, D. et al. 200I. "Accountability and Corruption: Political Institutions Matter." Political Research Working Paper 2708, Policy Research Dissemination Centre, 200I: I-39. https://openknowledge. worldbank.org/bitstream/handle/ıo986/ı9420/multiopage.pdf? sequence $=$. .

Linz, Juan. I990. "Transitions to Democracy." Washington Quarterly, I3, 3:143-64.

Linz, Juan and Stephan, Alfred. I996. "Toward Consolidated Democracies." Journal of Democracy, 7(2): I4-33.

Lumumba-Kasongo, T., ed. 2005. Liberal Democracy and its Critics in Africa: Political Dysfunction and the Struggle for Social Progress. Dakar: Council for the Development of Social Science Research in Africa.

Mafeje, A. I995. "Theory of democracy and African discourse." In Democratisation Processes in Africa: Problems and Prospects, edited by E. Chole $\&$ J. Ibrahim. Dakar: Council for the Development of Social Science Research in Africa.

Mainwaring, Scott and Scully, Timothy, eds. I995. Building Democratic Institutions: Party Systems in Latin America. Stanford: Stanford University Press.

Mainwaring, Scott, et al., eds. I992. Issues in Democratic Consolidation: The New South American Democracies in Comparative Perspective. Notre Dame: University of Notre Dame Press. 
Mcleod, R. H. 2005. "The struggle to regain effective government under democracy in Indonesia." Bulletin of Indonesian Economic Studies, 4I, 3: 367-386.

Merkel, R. 2006. "Comparative Constitutionalism and Rights: Separation of Powers-A Bulwark for Liberty and a Rights Culture." Saskatchewan Law Review, I29, 6: I29-I43

Mkandawire, T. I999. "Crisis management and the making of 'choiceless democracies." In State, Conflict and Democracy in Africa, edited by J Richard. Colorado \& London: Lynne Rienner Publishers

Mohtadi, H. and Roe, T. L. 2003. "Democracy, Rent Seeking, Public Spending and Growth." Journal of Public Economics, 87, 3-4: 445-466

Morlino, L. I995. "Democratic Consolidation: Definition and Models." In Transitions to Democracy, edited by G. Pridham. Aldershot: Dartmouth, pp. 57I-90.

Nye, Joseph. 1967. "Corruption and political development: A cost-benefit analysis." American Political Science Review, 5I, 2.

O’Donnell, G. I996. "Illusions about Consolidation." Journal of Democracy, 7, 2: 34-51.

Obute, P. E. 20I6. "Judicial Corruption and Administration of Justice in Nigeria." In The State in Contemporary Nigeria: Issues, Perspectives and Challenges, edited by I. Alumona and S. Omotola. Ibadan: John Archers.

Ogundiya, Sarafa. 20I0. "Corruption: The bane of democratic stability in Nigeria." Current Research Journal of Social Sciences, 2, 4: 235.

Ogundiya, Sarafa. 20II. "Party Switching and Defection in Nigeria: Implications for Democratic Consolidation." In Political Parties and Democratic Consolidation in Nigeria, edited by Sarafa Ogundiya. Ibadan: Codat Publication.

Ojo, Emmanuel. 2008. "Press Freedom and Democratic Consolidation in Nigeria Nascent Democracy (1999 -2007)." Unilag Journal of Politics, 4.I: I70.

Olarinmoye, O. O. 2008. "Godfathers, Political Parties and Electoral Corruption in Nigeria." African Journal of Political Science and International Relations. 2, 4 .

Omotola, J. S. 2009. "Nigerian Parties and Political Ideology." Journal of Alternative Perspectives in the Social Sciences, I, 3. 
Omotola, J. S. 20Io. "Political Parties and the Quest for Political Stability in Nigeria." Taiwan Journal of Democracy, 6(2).

Onoja, Martin. 2007. "Nigeria's Politics mired in Corruption and Violence." Guardian (Lagos), October Io, 2007.

Osipian, A. L. 2013. "Corruption and Democracy in Brazil: The Struggle for Accountability." Journal of Comparative Policy Analysis: Research and Practice, 20I3. https://my.vanderbilt.edu/araratosipian/ files/2013/04/BookRevBrazil20I3.pdf.

Osipitan, Taiwo. "Thoughts on independence and integrity of the judiciary." Daily Independence, October I3, 2005:I4.

Otite, Onigu. I986. “Sociological Study of Corruption.” In Nigeria: Corruption in Development, edited by Femi Odekunle, II-28. Ibadan: University Press.

Parekh, B. I993. "The cultural particularity of liberal democracy”. In Prospects for Democracy: North, South, East, West, edited by D Held. Cambridge: Polity Press.

Persson, T. et al. I997. "Separation of Powers and Political Accountability." Quarterly Journal of Economics, II2: II63-I2O2;

Przeworski, Adam. I991. Democracy and the Market. Cambridge: Cambridge University Press.

Ribadu, Nuhu. 20I6. "Nigeria's struggle with corruption." An abridged and edited version of presentation to US Congressional House Committee on International Development, Washington, DC, May I8, 2016.

Robison, R. and Hadiz, V. R. 2004. Reorganizing Power in Indonesia. New York: Routledge Curzon.

Rock, M. T. 2007. "Corruption and Democracy." Working Paper number 55, 2007. United Nations Department of Economic and Social Affairs. http://www.un.org/esa/desa/papers/2007/wp55_2007.pdf.

Rose-Ackerman, S. I996. "The Political Economy of Corruption: Causes and Consequences." View Point, 74: I-4.

Rutazibwa, Olivia U. 20I4. Back to Basics: Decolonizing Democracy in Africa: Europa World. http://www.europaworld.com/entry/ass.essay.25.

Saha, S. 20I4. "Democracy and Corruption: A Complex Relationship." Crime, Law and Social Change, 61, 3: 287-308.

Saliu, H and Bakare, R. 20I6. "An Assessment of the Performance of the $7^{\text {th }}$ National Assembly in Nigeria." A paper presented at a 2-Day National Conference on the Dynamic of Democratic Practice in Nige- 
ria, 1999-2015, organized by the Aminu Kano Centre for Democratic Research and Training, Mambayya House, Bayero University, Kano, Nigeria, November 9-10, 20I6: I-26.

Sandholtz, W. and Koetzle, W. 2000. "Accounting for corruption: economic structure, democracy, and trade." International Studies Quarterly, 44: 3I-50.

Schedler, Andre. I997. Concepts of Democratic Consolidation. Vienna: Institute for Advanced Studies.

Schiller, Chris. 2000. Improving Governance and Fighting Corruption: An IMF Perspective. Washington, DC: International Monetary Fund.

Schmitter, Philippe C. I995. "Transitology: The Science or the Art of Democratization?" In The Consolidation of Democracy in Latin America, edited by S. Joseph. Boulder and London: Lynne Rienner.

Shivji I. 2003. The Struggle for Democracy. www.marxists.org/subject/africa/ shivji/struggle- democracy.htm.

Svolik, M.V. 2007. "When and why democracies consolidate: Coups, incumbent takeovers, and democratic survival." SSM. http://ssrn. com/ abstract $=\mathrm{I} 337082$

Teshome-Bahiru, W. 2008. "Democracy and elections in Africa: Critical analysis." International Journal of Human Science, 5: 2(July). http:// ssrn.com/abstract=II64829.

The Nation Newspaper. 20I6. The National Newspaper. Lagos, July 31, 2016: 4 .

Thomson, A. 2000. A Introduction to African Politics. London/New York: Routledge.

Transparency International. I999. Corruption Perception Index. Berlin: Transparency International.

Villalon, L. A and Von Doepp, P., eds. 2006. The Fate of Africa's Democratic Experiments: Elites and Institutions. Bloomington: Indiana University Press.

Whitehead, Lauren. I989. "The Consolidation of Fragile Democracy." In Democracy in the America: Stopping the Pendulum, edited by R. Pastor. USA: Homes \& Meir.

World Bank, I997. Helping Countries Combat Corruption: Progress at the World Bank since 1997. Washington, DC: World Bank.

Yagboyaju, D. A. 20II. "Nigeria's Fourth Republic and the Challenge of a Faltering Democratization.” African Studies Quarterly, I2,3: 96-I03. 


\section{Abstract}

This article, adopting descriptive, historical and analytical methods of inquiry and using the post-authoritarian Nigeria as research backdrop, examines the contours and terrains of democratization processes, in Africa, under condition of pervasive corruption. It observes that democratic institutions, in Nigeria since the termination of the authoritarian order in I999, have performed abysmally in checking the incidences of corruption contrary to the expectations in the donor community, based on the experiences of the advanced democracies, that democracy and its appurtenances once launched, could reduced the incidence of corruption. It notes and argues that this state of affairs is not unconnected to a non-autonomous and a prebendal state, which offers almost limitless opportunities for official corruption to thrive.

\section{Keywords}

Democracy; democratization; authoritarianism; corruption; prebendalism.

Received on December 5, 2019 Accepted on May 13, 2019 